\title{
O INSÓLITO FICCIONAL E O DUPLO EM SONO, DE HARUKI MURAKAMI
}

\section{LÉA PERSICANO*}

Universidade Federal de Uberlândia (UFU), Programa de Pós-Graduação em Estudos Literários (PPLET), Uberlândia, MG, Brasil.

Recebido em: 19 jan. 2021. Aprovado em: 10 fev. 2021.

Como citar este artigo: PERSICANO, L. 0 insólito ficcional e o duplo em Sono, de Haruki Murakami. Cadernos de Pós-Graduação em Letras, v. 21, n. 1, p. 38-57, jan./abr. 2021. doi: 10.5935/cadernosletras. v21n1p38-57

\section{Resumo}

Neste artigo, de início, contextualizamos os estudos do fantástico, com uma síntese sobre o viés do gênero e o do modo, fundamentados em Marisa Martins Gama-Khalil (2013). Na sequência, analisamos a narrativa Sono, de Haruki Murakami, pela perspectiva do fantástico como modo discursivo, embasados em Remo Ceserani (2006) e Irène Bessière (1974). Utilizamos uma metodologia descritivo-analítica, objetivando destacar, analisar e compreender procedimentos narrativos e temas do fantástico na narrativa em foco, entre os quais se evidencia o duplo.

* E-mail: leapersicano@yahoo.com.br

(D) https://orcid.org/0000-0003-2325-5746 


\section{Palavras-chave}

Insólito. Sono. Duplo.

\section{CONTEXTUALIZAÇÃO DOS ESTUDOS DO FANTÁSTICO}

A dificuldade em se nomear a literatura que propicia o insólito em seu enredo, de acordo com a pesquisadora Marisa Martins Gama-Khalil (2013), é grande. De um lado, têm-se teóricos que definem os estudos na área em uma perspectiva genológica, com foco nas diferenças e na localização do fantástico na aproximação com gêneros vizinhos. De outro lado, estudiosos desenvolvem teorias na perspectiva modal, com destaque às diferenças e às semelhanças. Assim, a "construção da narrativa fantástica pode assumir variadas formas, agregar diversificados elementos e, dependendo da maneira como é tecida a sua trama, os estudiosos delegam a ela variáveis denominações" (GAMA-KHALIL, 2013, p. 19).

Apresentaremos uma rápida síntese dos autores que delinearam essas perspectivas com base no texto "A literatura fantástica: gênero ou modo?”, da pesquisadora em referência. No fantástico como gênero, destacam-se: Tzvetan Todorov, o teórico balizador e sistematizador dos estudos em literatura fantástica na década de 1960, para quem o fantástico ocorre pela incerteza/hesitação (do leitor, do personagem) e de uma recusa do leitor diante de uma interpretação alegórica e/ou poética (recusa essa que gera controvérsias entre alguns de seus estudiosos); Filipe Furtado (1980), em seu livro A construção do fantástico na narrativa, que, a partir de uma releitura e influência de Todorov, entende a emersão do fantástico em narrativas nas quais a ambiguidade permanece e que esta é interna à narrativa; David Roas (2001), que considera o fantástico vinculado à compreensão do real (pelo leitor e pelos personagens) e, como Furtado, vê o sobrenatural como elemento-chave para a tessitura da narrativa fantástica.

Sobre o fantástico como modo, embora Irène Bessière (1974) não tenha enunciado abertamente essa noção, desenvolveu um dos primeiros estudos a apontar a falibilidade da visão da literatura fantástica entendida como gênero, sendo contemporânea de Todorov (2004); para ela, a narrativa fantástica pressupõe uma lógica narrativa formal e temática visando à incerteza, com lastro em elementos sociais, culturais, históricos. Já Remo Ceserani (2006), alicerçado 
em Bessière, desenvolve um estudo acerca de procedimentos formais literários e temas recorrentes no modo fantástico - pesquisa na qual fundamentamos a seção seguinte deste artigo; Rosemary Jackson (1986), também influenciadora de Ceserani e Furtado (em uma fase mais recente - 2009), compreende as manifestações do modo fantástico por meio da fantasia, em histórias nas quais é possível perceber diversos temas e formas.

Mesmo que de forma indireta, escritos de Italo Calvino (2006) e Lenira Marques Covizzi (1978) - igualmente contemporânea de Todorov - remetem à perspectiva modal: ele, por utilizar a noção de fantasia (como Jackson) e pensar o espaço literário como um "espaço-cristal” (GAMA-KHALIL, 2013, p. 27), multifacetado, englobando, por exemplo, o maravilhoso e o fantástico; ela, por considerar o fantástico pela noção de insólito, que é ampla e abarca o "sentimento do inverossímel, incômodo, infame, incongruente, impossível, infinito, incorrigível, incrível, inaudito, inusitado, informal" (COVIZZI, 1978, grifos da autora apud GAMA-KHALIL, 2013, p. 28). Atualmente, o termo fantástico abrange diversas maneiras de se trabalhar com esse insólito, em vários jogos relacionais.

\section{UM OLHAR PARA A NARRATIVA POR MEIO DE PROCEDIMENTOS FORMAIS E SISTEMAS TEMÁTICOS DO FANTÁSTICO}

A narrativa Sono, do escritor e tradutor japonês Haruki Murakami (nascido em 1949), foi publicada pela primeira vez em 1990. Ela é dividida em seis capítulos e possui uma narradora em primeira pessoa - tipo de narração recorrente em textos do fantástico (CESERANI, 2006), que pode ou não nos deixar em dúvida sobre os acontecimentos descritos. Logo na primeira linha do seu relato (capítulo 1), ela nos situa em relação ao seu "drama" e, na sequência, nos apresenta uma opinião a respeito, justificando-a: "É o décimo sétimo dia em que não consigo dormir. Não se trata de insônia. Pois dela eu entendo um pouco" (MURAKAMI, 2015, p. 5). Faz uma regressão ao seu passado, à época da faculdade em que morava com a mãe, quando uma sonolência "parecida com insônia” acometeu-lhe em torno de um mês. Explica a nós, leitores, que sua consciência parecia estar ao seu lado, apartada do corpo, como uma sombra - o que também entendemos como um duplo. Esse 
[...] tema, nos textos fantásticos, se torna mais complexo e se enriquece, por meio de uma profunda aplicação dos motivos do retrato, do espelho, das muitas refrações da imagem humana, da duplicação obscura que cada indivíduo joga para trás de si, na sua sombra (CESERANI, 2006, p. 83).

A narradora-protagonista é uma mulher de trinta anos, graduada em Letras-Inglês, casada com um homem (dentista), mãe de um menino (pequeno), talvez pertencente a uma cultura japonesa (berço do autor Murakami), com uma rotina metódica, cujo senso de realidade gira em torno de um automatismo:

Meu dia a dia continua o mesmo de sempre: muito tranquilo e bem organizado. De manhã, após meu marido e meu filho saírem de casa, eu pego o carro para fazer compras. Meu marido é dentista e seu consultório fica a dez minutos de carro do prédio em que moramos (MURAKAMI, 2015, p. 13).

Um pouco mais à frente, ela reforça essa estrutura de vida:

Eu costumo ir com o [Honda] City fazer compras no supermercado. Ao voltar, limpo a casa e lavo as roupas. Preparo o almoço. [...] Inclusive, quando dá tempo, deixo o jantar pronto. Isso me permite ter a tarde toda para mim. Meu marido volta para almoçar em casa um pouco depois do meio-dia (MURAKAMI, 2015, p. 21).

Ou seja, ocupa o lugar de uma mulher com papéis sociais tradicionais, definidos, engessados, contextualizados cultural e historicamente: fazer compras, limpar a casa, lavar roupas, preparar as refeições principais (almoço e jantar), estar em casa no horário em que esposo e filho retornam. Notamos uma divisão de trabalho com base em questões de gênero: ele sai de casa para ganhar o sustento da família, enquanto ela se ocupa das tarefas domésticas. E também rastros do confucionismo, budismo e feudalismo:

Seguindo sua herança confucionista, a sociedade japonesa tende a valorizar o grupo ao invés do indivíduo. A família nesse caso seria um grupo e a mulher foi designada para ser a líder do seio familiar, cuidando do bem estar do marido e dos filhos. Já no budismo, existe uma crença de que a mulher deve ser subserviente ao marido.

Já como herança dos tempos feudais, notamos que quando as mulheres se casam, elas abdicam de sua vida profissional para viver em função do marido,

41 
dos filhos e das tarefas domésticas [...]. Já o marido, é responsável em trabalhar fora e arcar com os gastos que uma família demanda. (KAVANAMI, 2014).

Tais características indubitavelmente não são exclusivas à sociedade japonesa nem a definem, mas a marcam e não raras vezes a determinam, e à vida de muitas de nós, mulheres, em nossos contextos sociais. E consideramos importante destacá-las devido a textos fantásticos, como qualquer ficção, terem alicerces em elementos próprios ao real, seja de personagens, seja de leitores.

Além de atender a todas essas tarefas, a narradora-personagem ainda se mantém saudável e bonita de acordo com determinado padrão.

Assim que o meu marido retorna para o consultório, eu pego o meu maiô e a minha toalha e vou de carro até um clube esportivo nas redondezas. Costumo nadar durante trinta minutos. [...]. Não é que eu goste de nadar. Eu nado apenas porque não quero engordar (MURAKAMI, 2015, p. 23).

Após nadar, ou ela vai ao shopping, ou retorna para casa para ler ouvindo músicas e cochilar, tempo este que ela define como sendo somente seu.

O marido e o filho chegam no fim da tarde, e ela prepara um lanche. Enquanto o menino brinca com os amigos, arruma o jantar; jantam e os três conversam. O filho sobe para o quarto, ela o coloca para dormir e, depois o marido, após o tempo do casal a sós na sala. A essa rotina autômata se resume sua vida:

Ou melhor, era minha vida antes de eu não conseguir dormir. De um modo geral, todos os dias eram praticamente iguais, uma mera repetição. Eu escrevia um diário, mas se eu me esquecesse de escrevê-lo dois ou três dias já não sabia mais diferenciar um dia do outro (MURAKAMI, 2015, p. 28, grifo nosso).

Aqui, talvez ela mencione a prática da escrita no diário como uma "válvula de escape", uma forma de trabalhar com sua subjetividade; entretanto, havia se perdido em meio a tanta repetição, que esse ato/gesto tenha se tornado em vão.

Assim, estamos diante da realidade de uma mulher cujos dias não variam ou variavam muito pouco, e, com o fato de não conseguir dormir, tudo isso adquire outra dimensão. No início do capítulo 2, ela nos conta sobre uma lembrança da primeira noite sem dormir. Segundo Irène Bessière (1974, p. 4), 
[...] o relato fantástico é o lugar onde se exerce perfeitamente o trabalho da linguagem [...]. 0 discurso cultiva, fabrica e evoca. Toda descrição é uma confirmação, uma reconstrução do real, e, como evocação, é o chamado de uma realidade outra,

e essa reconstrução do real em uma outra realidade é o que acompanhamos por meio da narrativa em análise. A narradora-protagonista acorda de um pesadelo, imóvel, com o corpo sobressaltado e uma sombra adquire forma próximo à cama:

Forcei os olhos para tentar enxergar aquela sombra. Ao fitá-la atentamente, ela começou a tomar forma, como se aguardasse aquele meu olhar. Os contornos se tornaram nítidos, na forma de um corpo, e revelaram seus detalhes: era um velho magro de agasalho preto. Seus cabelos eram grisalhos, curtos, e as bochechas, fundas. [...] Seus olhos eram grandes e com os vasos sanguíneos vermelhos e dilatados. Seu rosto, porém, era desprovido de expressão (MURAKAMI, 2015, p. 33-34, grifo nosso).

É uma sombra escura, sombria, que tem o poder de paralisá-la. Na sequência, conforme o relato, o velho aguou ininterruptamente seus pés com um regador de cerâmica. Os pés não sentiam o toque da água, mas ela via a água sobre eles e ouvia o barulho desse movimento, que não cessava. Fechou os olhos, gritou bem alto e esse grito ecoou sem a emissão de som. Ele

[...] percorreu todas as minhas células, de ponta a ponta. Alguma coisa dentro de mim havia morrido. Como a onda que se segue à explosão, esse grito silencioso queimou muitas coisas relacionadas à minha existência, arrancando-as abruptamente pela raiz (MURAKAMI, 2015, p. 37).

Tem-se o misto de uma água e um grito curativos, em uma espécie de renovação celular, de perspectiva, entre outras possibilidades.

Percebemos, no aparecimento e na materialização dessa segunda sombra, outro momento de irrupção do insólito e do duplo. Para Julio França (2009, p. 7), "quando tomamos algo por insólito, estamos implicitamente admitindo que ele se desvia de - ou mesmo se opõe a - um certo grau zero, das coisas que consideramos ‘sólitas', e nada mais seria do que um duplo antagônico”. É pertinente observar, na citação recuada indicada anteriormente, que a narradora-personagem nos diz que a sombra (do velho) estava à espera do seu olhar para 
se materializar, e que o marido e o filho continuaram dormindo durante essa visita noturna. Isto é, a sombra era visível para ela e mais ninguém, como se dependesse do seu olhar para existir: “[a]pesar de ser uma extensão do sujeito, [...] o duplo não abandona sua condição de simulacro, de mera sombra, uma vez que não tem valor em si mesmo, mas apenas aquele que seu modelo lhe fornece" (FRANÇA, 2009, p. 8). E as projeções seguintes de si ao longo da narrativa, como se observa, seguem esse mesmo critério do duplo.

Enfatizamos que o ato de gritar - em função da água que nutria abundantemente os pés dela, mas que não deixou a cama molhada após o esvaecimento da sombra - lhe arrancou e queimou muitos incômodos existenciais. Embora essa sombra tenha suscitado na narradora-protagonista diferenças e não semelhanças, causando-lhe medo - ao contrário da primeira, na época da faculdade - talvez por ser um homem, idoso, averso a ela, um "duplo antagônico, possui uma força ainda mais terrível: o mal aqui é identificado não com o que é radicalmente diferente, mas com algo que mantém com o sujeito uma estranha familiaridade" (FRANÇA, 2009, p. 8). Tanto é que, com o passar do tempo, ela vai adquirindo uma lucidez sobre seu cotidiano e sentindo uma disposição física inexplicável.

Naquela noite, sentiu tanto medo e ficou tão abalada, que precisou de um banho (por causa do suor excessivo) e de uma bebida alcóolica (beber era um hábito que abandonou com o casamento). Ela ainda se interrogava:

"O que era aquele velho vestido de preto?", pensei. Nunca o tinha visto antes. Sua roupa preta também era muito estranha. [...] Quem era aquele homem? Por que que ele jogava água nos meus pés? [...] Não encontrava nada que fizesse sentido (MURAKAMII, 2015, p. 42).

Não conseguia explicar qualquer coisa, aparentemente não identificava nada familiar. Destacamos, com Ceserani (2006, p. 77-78), que a “ambientação preferida pelo fantástico é aquela que remete ao mundo noturno [...] A contraposição entre o claro e o escuro, sol e escuridão noturna é bastante utilizada no fantástico", criando efeitos que ocasionam medo, indefinição, angústia. Essa temática se confirma na narrativa em questão, pois as duas ocasiões até o momento em que as sombras se manifestam são durante a noite e a segunda sombra (a do velho) traja roupas escuras.

Como num retorno a um momento da vida em que era menos autômata, a narradora-personagem começou a reler um livro, Anna Karenina (de Liev 
Tolstói), considerando que logo pegaria no sono. Ao optar pela leitura, refletiu sobre o porquê parou de ler: "de uma hora para outra, habituei-me a uma vida sem leitura. Pensando bem, isso era muito estranho, pois, desde criança, minha vida gravitava em torno dos livros. [...] Por que será que a vida da gente muda de modo tão radical?” (MURAKAMI, 2015, p. 47-49). Na juventude, a leitura era a forma de interligá-la com mundos menos indiferentes e opressores que o familiar: o pai e a mãe trabalhavam muito, filha do meio entre cinco irmãos, abaixo dela duas irmãs mais novas para completar os estudos. Formou-se, saiu de casa, adquiriu independência financeira, casou-se e ficou na dependência do marido, reafirmando questões sociais, culturais e históricas.

Leu até o amanhecer, colocou o livro na mesa, foi para a cozinha e fez um café. "As cenas do romance, vívidas em minha mente, e a intensa fome que repentinamente comecei a sentir fizeram com que eu não conseguisse pensar em mais nada. Minha consciência e meu corpo pareciam estar desalinhados" (MURAKAMI, 2015, p. 53, grifo nosso). Esse livro, na narrativa Sono, exerce, de certa forma, a função de um objeto mediador entre o mundo real da leitora que nos conta os fatos que lhe ocorreram e o mundo dos personagens da história que ela lê. Inclusive, atua no fortalecimento da existência do duplo, pois ela considera a possibilidade de desalinhamento entre sua consciência e seu corpo. Envolve-se, de modo figurado, no romance entre Anna Karenina e Vronski, a ponto de descrever-se no lugar da protagonista em passagens do livro e de também projetar-se na garupa do cavalo junto com o amante. Karenina - como ela - é uma mulher casada, infeliz, mas - ao contrário dela - vive um caso amoroso fora do casamento e o tempo todo é assombrada por isso, em uma sociedade conservadora (Rússia, década de 1870), hipócrita, que a impede de conviver com o filho.

Quando o esposo e o filho saíram (capítulo 3), ela fez considerações acerca da rotina da manhã, constatando que não precisaria fazer compras ou ir ao banco. Entrega-se à leitura do livro - que lera antes, no ensino médio, porém não se lembrava do enredo - e, na segunda metade do primeiro volume, encontra um pequeno pedaço de chocolate ressecado pregado em uma das páginas. Esse chocolate - em conjunto com o livro - são

[...] objeto[s] que, com sua concreta inserção no texto, se torna[m] o testemunho inequívoco do fato de que o personagem protagonista efetivamente realizou uma viagem, entrou em uma outra dimensão de realidade e daquele mundo trouxe o objeto consigo (CESERANI, 2006, p. 74). 
Diante disso, a personagem passa a sentir uma imensa vontade de comer chocolate, vai até uma doceria perto de sua casa e compra duas barras. Começa a degustar uma delas no caminho e continua durante a leitura. Essa associação entre o chocolate e a leitura propiciadora de prazeres a acompanha desde a mocidade, tanto é que o chocolate seco dentro do livro aflora lembranças e a rememoração ocasiona um deslocamento entre mundos. Ainda que inconsciente, é como se Karenina, no relacionamento extraconjugal, realizasse os desejos mais secretos, o que ela goza pela leitura, bebida e doces.

Conforme a rotina pedia, interrompe a leitura para arrumar o almoço. Seu marido chega, almoça e insinua que queria fazer sexo. "Mas eu não estava nem um pouco a fim. Não entendia por que eu tinha de me sujeitar a fazer sexo. Eu queria voltar a ler o livro o quanto antes. Queria ficar sozinha e, deitada no sofá, ler Anna Karenina comendo chocolate" (MURAKAMI, 2015, p. 63). Isso a excitava, a satisfazia, enquanto a possibilidade do sexo sem tesão e por obrigação a chateava. Durante o tempo em que lava a louça, está imersa na leitura, pensando no personagem Vronski e no processo criativo do autor, Tolstói, que - segundo ela - controla e descreve os personagens de forma muito precisa. Nessa passagem e em diversas outras, visualizamos a sobrevida de personagens ficcionais em outro universo ficcional, assim como uma figurativização do próprio Tolstói na narrativa. Segundo Carlos Reis (2018, p. 485, grifo do autor), "[c]hama-se sobrevida de uma personagem ao prolongamento das suas propriedades distintivas, como figura ficcional, [...] noutras figurações", a "sobrevida concede à personagem uma existência autónoma, transcendendo o universo ficcional em que ela surgiu originariamente". Vronski é um homem viril e determinado; Karenina é uma mulher forte, apesar das forças sociais contrárias de sua época.

Com o marido de volta ao consultório odontológico, ela se questiona: "Por que será que eu não tinha sono? [...] deveria estar com tanto sono, mas tanto sono, que mal conseguiria ficar em pé. O fato é que agora eu não estava com sono, e minha consciência estava lúcida" (MURAKAMI, 2015, p. 65, grifo nosso). Apesar de querer continuar a leitura, vai ao clube para seu costumeiro nado de trinta minutos; porém, está tão estranhamente disposta, que nada quinze minutos a mais e com muito vigor, o que desperta olhares desconfiados dos presentes. Ficamos com a impressão de que o não dormir e o perder-se/encontrar-se na leitura davam-lhe cada vez mais vitalidade e lucidez. E ela segue o dia, entremeando a leitura com os afazeres e sem sono. A própria 
Karenina - mulher abastada com quem ela se (des)identifica - tem uma dupla existência, fases de vigor entremeadas a abatimentos e decepções, apresentando tentativas de ressurgimento dos problemas. Em alguns momentos, as infelicidades familiares da vida de ambas se tocam, mas aquela buscou mudanças abertamente, enquanto esta, não.

O capítulo 4 se inicia com o fim do dia descrito anteriormente: ela finge que dorme e volta para a sala, em busca do seu amante (o livro), para prosseguir com a leitura. Nessa vida dupla, o conhaque e o chocolate também continuam sendo suas companhias noturnas; o conhaque como um prazer que inebria, deixando os sentidos mais soltos e o chocolate como um estimulante. Nesses momentos, seu gozo parece pleno, mas é interrompido pelo amanhecer; e, mais uma vez, ela reforça o seu dia a dia, no qual seu bem-estar é encontrado nos intervalos:

Todos os dias era a mesma coisa.

Eu terminava rapidamente as tarefas domésticas e, no período da manhã, ficava lendo o livro. Na hora do almoço, parava a leitura e preparava a refeição. Depois que meu marido saía de casa, um pouco antes da uma, eu pegava o carro e ia nadar na piscina. Desde o dia em que eu não conseguia mais dormir, diariamente passei a nadar durante uma hora. [...] Após nadar o que podia, a única coisa que eu queria era voltar o mais rápido possível para casa e continuar a leitura.

Como parte das minhas obrigações eu fazia as compras, preparava as refeições e dava atenção ao meu filho. Por obrigação eu fazia sexo com meu marido (MURAKAMI, 2015, p. 69-71, grifos nossos).

Curioso que ela saiu de uma rotina (em que vivia como autômata, não fazia quase nada do que gostava, o nível de afeição pelo filho é mediano e os sentimentos pelo marido soam como comodidade) e entrou em outra (em que predomina a leitura de um livro que a toca, tem um vigor físico incomum - o contato com a água também lhe proporciona isso e outros confortos, encontra tempo para si à noite enquanto os outros membros da sua família dormem). E essa rotina atual possui outros diferenciais, parece que o senso crítico e a percepção da narradora-protagonista relativos à sua realidade mudaram:

0 hábito torna as tarefas simples de serem realizadas. Pode-se dizer que elas se tornam fáceis. Basta desconectar a mente do corpo. Enquanto meu corpo se movimentava à vontade, minha mente pairava em seu próprio espaço exclusivo. [...] 
Depois que deixei de dormir passei a considerar fácil administrar a realidade. De fato, cuidar da realidade é uma atividade muito simples. Era tão somente a realidade. Consistia apenas em tarefas domésticas (MURAKAMI, 2015, p. 71-72, grifos nossos).

O que acabou fortalecendo a criação de um mundo à parte, ou melhor, que ela vivesse em dois mundos paralelos: um em que nutre as necessidades do esposo, do filho, da sogra, de si como mulher ideal para a sociedade; e outro em que abre espaço para viver com certa liberdade, entregando-se com fervor a coisas que lhe dão prazer (leitura literária praticamente ininterrupta, bebida alcóolica, doces); além de outros mundos possíveis.

Esse momento da narrativa, de certo modo, nos remete à discussão de Roland Barthes (1988), que disserta sobre três forças da literatura relacionadas respectivamente a três conceitos gregos - Mathesis, Mimesis, Semiosis: 1. assumir vários saberes; 2. a representação; e 3. a semiologia. Acerca da primeira força, o autor entende que literatura "é a realidade, isto é, o próprio fulgor do real [...] encena a linguagem, em vez de, simplesmente, utilizá-la" (BARTHES, 1988, p. 18-19); sobre a segunda força, ele considera que o "real não é representável [...] somente demonstrável" (BARTHES, 1988, p. 21); e a respeito da terceira força, “[c]hamaria de bom grado 'semiologia' o curso das operações ao longo do qual é possível - quiçá almejado - usar o signo como um véu pintado, ou ainda uma ficção" (BARTHES, 1988, p. 39).

Notamos que todas essas forças da literatura atuam em conjunto e propiciam à leitora/ao leitor entrar em contato com realidades fulguradas e encenadas, um real demonstrável e a criação ficcional por meio de signos. No caso, podemos especificar como leitora a mulher que lê Anna Karenina em Sono, pois o livro suscita nela uma profunda identificação com a história e os personagens de Tolstói (e por que não considerar a mulher que lê Sono e escreve este artigo, já que também se identifica profunda e estranhamente com a história e a personagem de Murakami?). Acerca de ambiguidades na narrativa fantástica do ponto de vista modal, ao qual nos dedicamos neste texto, Ceserani (2006, p. 69) destaca que "há a vontade e o prazer de usar todos os instrumentos narrativos para atirar e capturar o leitor dentro da história, mas há também o gosto e o prazer de lhe fazer recordar sempre de que se trata de uma história"; igualmente, o modo fantástico privilegia as "potencialidades criativas da linguagem (as palavras podem criar uma nova e diversa 'realidade')" (CESERANI, 
2006, p. 70) - o que vimos com Bessière (1974) sobre a narrativa fantástica e com Barthes (1988) acerca da literatura em geral.

Retornando à companhia da narradora-personagem, ela realça que sua mudança não foi notada por ninguém, da mesma forma "[n]inguém percebeu que eu não dormia, que eu estava lendo um livro extenso e que minha mente estava a centenas de anos, a milhares de quilômetros de distância da realidade" (MURAKAMI, 2015, p. 73), o que demonstra que os familiares não prestavam atenção nela nem davam valor às suas opiniões. Transcorreu uma semana sem dormir e, ao entrar na segunda semana, foi ficando preocupada: "Queira ou não, era algo anormal. As pessoas dormem, e não existem pessoas que não dormem. [...] Não lembro quanto tempo levava para a pessoa ficar louca. Mas, se não me engano, era em torno de três a quatro dias" (MURAKAMI, 2015, p. 73-74, grifo nosso). Percebemos, nesse momento, uma inquietação relativa à passagem de limite

[...] da dimensão da realidade para a [da falta] do sono [...] ou da loucura. 0 personagem protagonista se encontra repentinamente como se estivesse dentro de duas dimensões diversas, com códigos diversos à sua disposição para orientar-se e compreender (CESERANI, 2006, p. 73).

Estão em jogo parâmetros de normalidade e anormalidade sociais. O que, em certo sentido, equivale a dizer, indo a Bessière (1974, p. 4, grifos da autora), que o "fantástico instaura a desrazão na medida em que ultrapassa a ordem e a desordem [...] ele se alimenta inevitavelmente das realia, do cotidiano [...] no relato, nasce do diálogo do sujeito com suas próprias crenças e inconsequências".

Entretanto, a narradora-protagonista, ao contrário de se sentir debilitada, enuncia-se bastante saudável e conta-nos uma autopercepção em frente do espelho:

Certo dia, depois do banho, fiquei nua diante do espelho de corpo inteiro. E me surpreendi ao notar que meu corpo irradiava vitalidade. [...]

Constatei que eu estava muito mais bonita do que pensava. Até me achei jovem. Podia passar por uma moça de vinte e quatro anos. Tinha a pele lisa e os olhos brilhantes. Os lábios viçosos e as bochechas, (esta era a parte que eu mais detestava no meu rosto), que até então eram salientes, já não chamavam mais a atenção. Sentei-me diante do espelho e contemplei meu rosto em silêncio por cerca de trinta minutos. Observei-o de vários ângulos e com um olhar objetivo. Não havia me enganado. Eu realmente estava bonita (MURAKAMI, 2015, p. 74-77, grifos nossos). 
Verifica que está deveras bonita e jovem, sua pele sem indício de rugas e seus olhos com um brilho vigoroso, os lábios e as bochechas harmônicos em comparação ao todo do rosto. Este, agora, não mais a desagrada. Por esse motivo, consideramos importante trazer à tona outros dois momentos (anteriores) da narrativa em que ela descreve sua relação com o próprio corpo, mediada pelo espelho:

Mas, para ser sincera, nunca gostei do meu rosto. Ele não é de todo ruim, mas, mesmo assim, não consigo gostar dele. Em compensação, eu gosto do meu corpo. Gosto de ficar nua em frente ao espelho; de contemplar seu delicado contorno e sentir nele a presença de uma harmoniosa vitalidade. Eu sinto que ele possui algo que é muito importante para mim. Não sei exatamente o que é (MURAKAMII, 2015, p. 23, grifos nossos).

Eu me sentia simplesmente assustada. [...] eu ficava em frente ao espelho do banheiro contemplando meu rosto. [...] Observava detidamente o meu rosto como se ele fosse apenas um objeto. Ao fozer isso, meu rosto gradativamente se dissociava de mim e passava a ser uma coisa com vida própria. Essa dissociação me ajudava a tomar consciência do meu presente [...] a minha existência (MURAKAMI, 2015, p. 28-29, grifos nossos).

Ela ressalta, na primeira passagem, o que gosta (do próprio corpo e de ficar nua diante do espelho) e o que não gosta (do próprio rosto); já na segunda passagem, ela destaca que, ao mirar o rosto no espelho como um objeto, é como se ele adquirisse vida autônoma e possibilitasse a ela refletir sobre seu presente. Quando sentia angústia pelo tipo de vida que levava, observava-se no espelho e o rosto, levemente envelhecido, a fazia voltar-se para si e seu entorno. A pessoa que tinha se tornado a assustava.

Observamos que essa relação com o espelho e suas projeções nele se modificam na medida em que ela permanece sem dormir. Como se passasse de um duplo estranho para um duplo perfeito, de uma aceitação parcial de si (do corpo menos o rosto) para uma aceitação total (do corpo incluindo o rosto). O espelho, de acordo com Michel Foucault (2006), consiste em um tipo de experiência mista entre as utopias e as heterotopias. Como utopia, um lugar sem lugar,

[...] [n]o espelho, eu me vejo lá onde não estou, em um espaço irreal que se abre virtualmente atrás da superfície, eu estou lá longe, lá onde não estou, uma 
espécie de sombra que me dá a mim mesmo minha própria visibilidade, que me permite me olhar lá onde estou ausente (FOUCAULT, 2006, p. 415).

Como heterotopia, o espelho tem existência real e efeito retroativo para quem se posiciona diante dele:

[...] a partir do espelho que me descubro ausente no lugar em que estou porque eu me vejo lá longe. A partir desse olhar que de qualquer forma se dirige para mim, do fundo desse espaço virtual que está do outro lado do espelho, eu retorno a mim e começo a dirigir meus olhos para mim mesmo e a me constituir ali onde estou (FOUCAULT, 2006, p. 415).

Nesse jogo de olhares com o espelho, simultaneamente há um espaço real e um irreal. E é nessa confluência de espaços e percepções que a narradora-personagem se reconfigura. Ora seu olhar vislumbra a utopia de uma mulher projetada socialmente como perfeita/melhorada, uma sombra que reprojeta sua forma de se ver, com a qual pode ou não se identificar. Ora sua percepção convida a questionar o que enxerga, comparando o estado atual de seu corpo/ sua vida com anterior(es), aceitando (ou não) o que vê.

Retomemos a questão da desrazão/da loucura que ora incomoda a narradora-protagonista. Ela relata ter pensado em buscar ajuda médica, mas acredita que o médico "vai achar que estou com algum distúrbio mental, ou vai dizer que estou com neurose decorrente da insônia. Ou então ele vai acreditar em mim e me encaminhar para algum hospital para fazer exames" (MURAKAMI, 2015, p. 78, grifos nossos). Questiona-se dentro de padrões de (a)normalidade social e o que aconteceria depois. O que ela quer é ficar sozinha, lendo com tranquilidade o livro, também nadar por uma hora e, acima de tudo, sua liberdade. Procura uma biblioteca em busca de livros sobre o sono e encontra poucos, que se resumem a explicar que o sono é um período de repouso, a fim de recarregar as energias do corpo e da mente. Um dos livros chamou-lhe a atenção por explicar que os seres humanos desenvolvem padrões de comportamento, tendências próprias, e que o sono atua na correção e no equilíbrio dessas tendências. As delas, pensou, se referem às tarefas domésticas e não precisa dormir, pois

[...] [n]ão me importo de ficar louca ou de perder o cerne da minha existência. [...] Se para me curar desse desgaste provocado por essa tendência é necessário dormir periodicamente, não vou fazer isso. Não preciso dormir. Se por um lado o 
meu corpo vai ser consumido pela tendência, por outro sei que minha mente será somente minha. [...] Não quero ser curada. Não vou dormir (MURAKAMI, 2015, p. 83, grifos nossos).

A possibilidade da loucura, nesse outro momento, não a incomoda, uma vez que a vida que possuía - e é altamente alienadora - a consumia muito mais. O que nos faz lembrar das explicações de Foucault (2009, p. 30) acerca da loucura:

A loucura torna-se uma forma relativa à razão, ou melhor, loucura e razão entram numa relação eternamente reversível que faz com que toda loucura tenha sua razão que a julga e controla, e toda razão sua loucura na qual ela encontra sua verdade irrisória.

O sono, nesse caso, está para uma razão imbecil e possibilita uma ligação entorpecedora entre o corpo e a mente; a falta dele, por sua vez, está para uma loucura lúcida e desmembra o corpo da mente/consciência, e essa - o duplo da narradora-personagem - passa apenas a lhe pertencer e a mais ninguém. Ceserani (2006, p. 83) sublinha que, “no fantástico, o tema [do duplo] é fortemente interiorizado, e ligado à vida da consciência, das suas fixações e projeções", o que se reforça no desenrolar da narrativa.

Tendo assumido que não precisava mais dormir (eis o capítulo 5), deixa de temer a falta do sono e a compreende como uma expansão da sua vida e do seu tempo. Teria o período da madrugada somente para ela: "Nesse período, ninguém vai me incomodar nem me requerer. Isso sim significa expandir a vida. Eu havia ampliado a minha vida em um terço" (MURAKAMI, 2015, p. 84). Quinze dias já haviam se passado, releu Anna Karenina três vezes e, agora, lia outros livros de Tolstói. Reabastecia o estoque de leitura, bebidas e doces. $\mathrm{O}$ ânimo progressivamente acentuado e a vida dupla acontecendo, agora com outros acontecimentos externos, sem que os familiares percebessem (como acontecia na juventude):

Às vezes, no decorrer da leitura, eu ficava extremamente estimulada. Nessas horas, eu deixava o livro de lado e ia para o quarto me exercitar. [...] Quando me dava vontade, saía de madrugada. Trocava de roupa, tirava o carro da garagem e vagava sem rumo pelas redondezas. Entrava numa dessas lanchonetes vinte e quatro horas e tomava um café [...]. De vez em quando, estacionava em algum local aparentemente seguro e me perdia em pensamentos (MURAKAMI, 2015, p. 88). 
De novo em casa, quando observava seu marido dormir e fitava seu rosto, ia notando-o mais velho e feio - ao contrário dela, que se via no espelho mais jovem e bonita. Precisou olhar o rosto do seu filho, porque se sentia incomodada com algo e, com muito custo, entendeu que seu rosto era como o do pai e o da avó, sua sogra. Detestava a arrogância da família e, com o tempo, acreditava que deixaria de gostar do filho, o que pensava ser inapropriado para uma mãe. O que lhe aconteceria? Seus pensamentos e sentimentos oscilam, novamente, entre padrões sociais de comportamento do que é ou não aceitável para uma mulher de respeito. Lembremos que Karenina foi tachada de vadia e teve o direito da convivência com o filho negado, apesar de o marido supor que não gostaria mais do filho por associá-lo com a traição da esposa, sentimento que não sofria julgamento social quando vinha do homem. Karenina teve uma terrível morte: suicidou-se pulando na frente de um trem.

Há dezessete noites e dias acordada, a narradora-protagonista fecha os olhos para se lembrar daquela sensação provocada pelo sono. De olhos fechados, associa o sono e sua ausência com a morte:

Até então, eu achava que o sono era um tipo de morte. [...] a morte era um sono bem mais profundo, sem consciência. Um descanso eterno, um blecaute. [...] Será que a morte não seria uma escuridão profundamente consciente e infinita, como a que estou presenciando agora? (MURAKAMIl, 2015, p. 100).

De repente, é acometida por um medo profundo, quase paralisante. Ao abrir os olhos, sorve o gole final do conhaque na taça.

O sexto e último capítulo se inicia com ela tirando o pijama, vestindo

[...] um jeans e uma jaqueta sobre uma camiseta. Prendo os cabelos para trás, enfio-os embaixo da jaqueta e coloco o boné de beisebol do meu marido. Ao me olhar no espelho, eu pareço um homem. Assim está ótimo. Calço os tênis e desço até a garagem no subsolo (MURAKAMI, 2015, p. 102, grifo nosso).

Ela sai de carro e dirige até um parque, onde estaciona e afunda o boné na cabeça para não ser identificada como mulher. Torna-se curioso pensar que, nessa passagem, ela pretendia se passar por um homem e o espelho confirma essa aparência; além disso, tendo adquirido um grau de consciência expressivo acerca das fragilidades e repetições mecânicas de sua vida no grupo familiar, sabia que - como mulher - estaria mais sujeita a agressões físicas fora de casa no período noturno. 
Reflete, então, sobre algumas lembranças e conclui que mudou. Fica por ali no estacionamento, de olhos fechados, observando a escuridão na ausência do sono. Será que seu desejo era morrer? Passa-nos a impressão de que não via mais o menor sentido em viver como uma autômata, programada. Repentinamente, nota a presença de alguém; e, mais uma vez, há a "aparição do estranho, do monstruoso, do irreconhecível” (CESERANI, 2006, p. 84): abre os olhos e há

[...] duas sombras negras, uma de cada lado do carro. [...] Eu não consigo ver seus rostos. Nem as roupas que vestem. [...] bato a testa com força no volante. [...] As lágrimas não param de cair. Estou presa nesta caixinha [...]. 0 que eles querem é virar o meu carro (MURAKAMl, 2015, p. 108-110, grifo nosso).

Se são homens ou sombras indefinidas, não sabemos ao certo; tampouco o fim exato da narradora-personagem. Esse final da história reforça a temática da noite, do duplo, do não reconhecido, e abre "espaços vazios, de elipses na escritura. No momento culminante da narração, quando a tensão está alta no leitor, e é forte a curiosidade de saber, se abre de repente sobre a página um buraco branco, a escritura povoada pelo não dito" (CESERANI, 2006, p. 74, grifos nossos).

\section{CONSIDERAÇÕES FINAIS}

Dentre os procedimentos narrativos e retóricos comumente usados pelo modo fantástico e elencados por Ceserani (2006), ganham evidência em Sono: a narração em primeira pessoa; posição de relevo dos procedimentos narrativos no próprio corpo da narração; um forte interesse pela capacidade projetiva e criativa da linguagem; envolvimento do leitor: surpresa; passagem de limite e de fronteira; o objeto mediador; as elipses. Dos sistemas temáticos recorrentes na literatura fantástica, sobressaem: o duplo (por meio das sombras, da consciência e do espelho); a noite e a escuridão; a loucura; a aparição do estranho, do monstruoso, do irreconhecível.

Murakami, o autor da narrativa analisada, escreveu o texto de maneira tão multifacetada e cadenciada, que sua narradora descreve minuciosamente o dia a dia dela, construindo em nós, leitores e leitoras, a percepção/imagens, por 
exemplo, da vida da protagonista: mulher, casada, mãe, dona de casa, razoavelmente bonita, realiza atividade física com regularidade, possui uma rotina metódica e repetitiva. Até o dia em que uma visita noturna estabelece uma nova configuração rotineira, a partir da ausência do sono, estando incluídos nessa reconfiguração os prazeres advindos da literatura, da bebida alcoólica e de doces. O rotineiro - chamado por alguns de seus leitores de "vulgar" - oferecido pelo autor causa estranhamento não só à narradora-protagonista, mas também a nós que acompanhamos sem pestanejar o seu relato.

E, para encerrar, trazemos Barthes (1988, p. 19) novamente ao diálogo: na literatura, "as palavras não são mais concebidas ilusoriamente como simples instrumentos, são lançadas como projeções, explosões, vibrações, maquinarias, sabores: a escritura faz do saber uma festa"; em conjunto com Gama-Khalil (2019, p. 20), que afirma ser a literatura fantástica

[...] uma máquina de ver, porém um "ver mais além"', ação propiciada pelo procedimento de uma singularização que atinge um plus ultra - discursiva e diegeticamente - porque nos permite ter uma visão que conjuga o vivido com o sonhado e o inventado.

Trata-se de uma visão para imagens convidativas ao prazer decorrente do estranhamento. Assim, os textos literários podem causar-nos estranhamentos, (des)identificações, reflexões, levando-nos a sair dos automatismos diários.

\section{The uncanny and the double in Sleep, by Haruki Murakami}

\section{Abstract}

In this article, the fantastic literature studies were contextualized with a synthesis on the outlook on the genre and the mode theoretically based on Marisa Martins Gama-Khalil (2013). After that, the narrative in Sleep by Haruki Murakami was analyzed from the fantastic literature perspective as a discursive mode theoretically based on Remo Ceserani (2006) and Irène Bessière (1974). Hence, a descriptive-analytical methodology was applied to highlight, analyze, and understand the narrative procedures and themes of the fantastic literature in this tale, in which the double is quite evident. 


\section{Keywords}

Uncanny. Sleep. Double.

\section{REFERÊNCIAS}

BARTHES, R. Aula. São Paulo: Cultrix, 1988.

BESSIÈRE, I. Le récit fantastique. La poétique de l'incertaine. Paris: Larousse, 1974.

CALVINO, I. Definições de territórios: o fantástico. In: CALVINO, I. Assunto encerrado: discursos sobre literatura e sociedade. São Paulo: Companhia das Letras, 2006. p. 256-258.

CESERANI, R. Procedimentos formais e sistemas temáticos do fantástico. In: CESERANI, R. O fantástico. Curitiba: Editora 2006. p. 67-88.

COVIZZI, L. M. O Insólito em Guimarães Rosa e Borges. São Paulo: Ática, 1978.

FOUCAULT, M. Outros espaços. In: FOUCAULT, M. Ditos \& escritos III - Estética: literatura e pintura, música e cinema. Organização Manoel Barros da Motta. 2. ed. Rio de Janeiro: Forense Universitária, 2006. p. 411-422.

FOUCAULT, M. História da loucura: na idade clássica. 8. ed. São Paulo: Perspectiva, 2009.

FRANÇA, J. Apresentação: O insólito e seu duplo. In: GARCÍA, F.; MOTTA, M. A. (org.). O insólito e seu duplo. Rio de Janeiro: EdUERJ, 2009. p. 7-14.

FURTADO, F. A construção do fantástico na narrativa. Lisboa: Livros Horizonte, 1980.

FURTADO, F. Fantástico (Modo). E-dicionário de termos literários, 26 dez. 2009. Disponível em https://edtl.fcsh.unl.pt/encyclopedia/fantastico-modo/. Acesso em: 19 abr. 2021.

GAMA-KHALIL, M. M. A literatura fantástica: gênero ou modo? Terra roxa e outras terras - Revista de Estudos Literários, v. 26, p. 18-31, dez. 2013.

GAMA-KHALIL, M. M. O discurso e a diegese do fantástico: o plus ultra da singularização. In: SANTOS, L. A.; GABRIEL, M. A. R.; DANTAS, M. B. S. (org.). Reflexões sobre o insólito ficcional. João Pessoa: Editora UFPB, 2019. p. 11-23.

JACKSON, R. Fantasy: Literatura y Subversión. Buenos Aires: Catalogos Editora, 1986. 
KAWANAMI, S. A importância da mulher na sociedade japonesa. Japão em Foco, 8 mar. 2014. Disponível em: https://www.japaoemfoco.com/a-importancia-da-mulherna-sociedade-japonesa/>. Acesso em: 7 jan. 2021.

MURAKAMI, H. Sono. Ilustrações Kat Menschik. Rio de Janeiro: Objetiva, 2015.

REIS, C. Dicionário de estudos narrativos. Coimbra: Almedina, 2018.

ROAS, D. La Amenaza de lo Fantástico. In: ROAS, D. (org.). Teorías de lo Fantástico. Madrid: Arco: Libros S.L., 2001. p. 7-44.

TODOROV, T. Introdução à literatura fantástica. 3. ed. São Paulo: Perspectiva, 2004. 